\title{
Are two heads better than one? Evidence from the thrift crisis
}

\author{
John Byrd $^{\mathrm{a}}$, Donald R. Fraser ${ }^{\mathrm{b}}$, D. Scott Lee ${ }^{\mathrm{b}, *}$, Semih Tartaroglu ${ }^{\mathrm{c}}$ \\ a Business School, University of Colorado Denver, Denver, CO 80202, USA \\ ${ }^{\mathrm{b}}$ Mays School of Business, Texas AE'M University, College Station, TX 77843, USA \\ ${ }^{c}$ W. Frank Barton School of Business, Wichita State University, Wichita, KS 67260, USA
}

\section{A R T I C L E I N F O}

\section{Article history:}

Received 4 March 2011

Accepted 8 October 2011

Available online 20 October 2011

\section{JEL classification:}

G38

G21

G28

Keywords:

Unitary leadership

CEO duality

Financial regulation

Financial crises

Corporate governance

\begin{abstract}
A B S T R A C T
We employ a natural experiment from the 1980s, predating the ubiquitous clamor for independence influenced corporate governance structures, to examine which governance mechanisms are associated with firm survival and failure. We find that thrifts were more likely to survive the thrift crisis when their CEO also chaired the firm's board of directors. On average, chair-holding CEOs undertook less aggressive lending policies than their counterparts who did not chair their boards. Consequently, taxpayer interests were protected by thrifts that bestowed both leadership posts to one person. This is an important policy issue, because taxpayers become the residual claimants for depository institutions that fail as a result of managers adopting risky strategies to exploit underpriced deposit insurance. Our findings corroborate recent evidence that manager-dominated firms resist shareholder pressure to adopt riskier investment strategies to exploit underpriced deposit insurance.
\end{abstract}

(ㄷ) 2011 Elsevier B.V. All rights reserved.

\section{Introduction}

On May 18, 2010, California Public Employees' Retirement System (CalPERS) cast 12.7 million votes for a shareholder proposal to separate the posts of chief executive officer (CEO) and chair at JPMorganChase. CalPERS had voted for a similar split at Goldman Sachs two weeks earlier. Three proposals introduced in the US Congress would require "public companies to split the jobs of CEO and Chairman of the Board". ${ }^{1}$ This is consistent with public policy in the United Kingdom, which either prohibits or strongly discourages unitary leadership (one individual simultaneously chairing the board and serving as CEO). ${ }^{2}$ This pressure appears to have influenced the likelihood of joint CEO-chair appointments. In 1988, 80.9\% of the firms in the Forbes Executive Compensation Survey had one person

\footnotetext{
* Corresponding author. Tel.: +1 979845 4840; fax: +1 9798453884.

E-mail addresses: john.byrd@ucdenver.edu (J. Byrd), DFraser@mays.tamu.edu (D.R. Fraser), slee@tamu.edu (D. Scott Lee), Semih.Tartaroglu@wichita.edu (S. Tartaroglu).

1 As of December 11, 2010, S. 1074: Shareholder Bill of Rights of 2009, H.R. 3272: Corporate Governance Reform Act of 2009, and H.R. 2861: Shareholder Empowerment Act of 2009 all remain under committee consideration.

2 Following Brickley et al. (1997, p. 192), we adopt terminology drawn from Alexander Hamilton's 1788 essay on the advantages of a single executive in The Federalist Papers. Thus, the adjectives unitary and dual are organizational characteristics with unitary leadership referring to a single CEO/Chairman and dual leadership referring to two leaders.
}

filling both posts (Brickley et al., 1997). Favaro et al. (2010) report that "(a)t the outset of the decade [2000], roughly half of the North American and European CEOs entering office were named chairman and CEO. In 2009s incoming class, that number had fallen to $16.5 \%$ in North America and 7.1\% in Europe". ${ }^{3}$

Extensive attention has been devoted to the perversity of shareholder interests (e.g., CalPERS) in the presence of the moral hazard of deposit insurance (e.g., Akerlof and Romer, 1993; Diamond and Dybvig, 1983 and Diamond and Dybvig, 1986). The purpose of this paper is to question whether splitting the CEO and chair's post is an appropriate policy for Congress, whose presumed constituency is taxpayers.

The empirical evidence on splitting the CEO and chair posts is mixed and subject to skepticism because widely recognized endogeneity problems plague most analyses (see Adams et al., 2005; Bhagat and Bolton, 2008 and Brickley et al., 1997). Still, the current literature provides no evidence of costs incurred from separating the CEO's authority from that of the chair, so are proposals for mandatory separation of the posts simply innocuous gestures? ${ }^{4}$

\footnotetext{
${ }^{3}$ Grinstein and Valles (2008) detect a similar trend away from unitary leadership over the 2000-2004 interval.

${ }^{4}$ Dey et al. (2009) report significantly lower announcement returns to firms that split the duties of their CEO and chair; however, they exclude financial institutions from their analysis.
} 
Evidence of any negative effects of unitary leadership structure relies on accounting or stock return performance of non-financial firms during favorable or benign economic environments and rests squarely on the presumption that shareholders bear the firm's residual risk. However, Blair and Stout (2001), Baird and Rasmussen (2007) and others contend that the put option afforded by limited liability contradicts the view of shareholders as residual claimants. This contention is buttressed by evidence of creditor control of financially distressed firms (e.g., Chava and Roberts (2008) and Nini et al. (2009)). The Troubled Asset Relief Program (TARP) bailouts dispelled any lingering doubts of the inadequacy of the shareholder primacy perspective. As FDIC chairperson Sheila Bair recently stated, these circumstances encourage "executives to take excess risks with the hope that these bets will pay off. ... The taxpayer remains liable for any losses, but the shareholders profit if these investments result in gains". 5

Recent work by Beltratti and Stulz (2011), Erkens et al. (2010), and Fahlenbrach and Stulz (2011) contradicts the view that enhanced shareholder control might have avoided the short-term risk taking pattern that became apparent during the most recent credit crisis. They show that banks whose CEO incentives were better aligned with shareholder interests actually performed worse during the 2008 credit crisis than other banks. This result holds across banks that did and did not receive TARP assistance. In fact, Adams (2011) finds that banks that received TARP assistance had greater board independence than other banks.

Laeven and Levine (2009) and Gropp and Köhler (2010) extend this line of inquiry to banks in 48 and 25 countries, respectively, controlling for and exploiting the variability in their uneven regulatory and legal conditions. Laeven and Levine examine the 19962001 period and conclude that banks with more powerful owners are more likely to take greater risks. Gropp and Köhler contrast the performance of manager-controlled banks and owner-controlled banks before and during the 2008 credit crisis. Both groups perform worse during the crisis than they performed during prosperous periods, but the performance of manager-controlled banks is less erratic than their owner-controlled counterparts. Managercontrolled banks' average annual ROE is $6.3 \%$ pre-crisis and $1.3 \%$ in 2008. In contrast, owner-controlled banks' annual ROE averages $30.1 \%$ pre-crisis and $-0.9 \%$ in 2008 . Gropp and Köhler conclude "that owner-controlled banks took greater risk in the pre-crisis period and, thus, needed greater financial support from the government than manager-controlled banks once the crisis started to unfold and the incurred risks to materialize".

These studies corroborate evidence from 1997 to 2004 by Pathan (2009), who concludes that banks with manager-controlled boards are more likely to avoid risk than their ownercontrolled counterparts. Although Pathan does not consider unitary leadership separately, he does include unitary leadership in an index of CEO power and concludes that powerful CEOs are better able to resist deposit insurance's risk ratcheting incentives. CEO risk aversion may reflect their undiversified human and financial capital that may lead them to offset the high-risk preferences of shareholders. Pathan's results complement the earlier risk analysis of Anderson and Fraser (2000) and Simpson and Gleason (1999), who conclude that shareholders compel banks to seek more risk during periods of financial distress and low bank franchise value, in order to exploit the non-linear payoff from underpriced deposit insurance and "too big to fail" governmental policies. They also are consistent with the findings of Saunders et al. (1990, p. 643) that "shareholder controlled banks exhibit significantly higher risk taking behavior than man-

${ }^{5}$ Wessel, David. "Small Banks and Big Risks", Wall Street Journal, June 24, 2010, p. 2. agerially controlled banks during the 1979-1982 period of relative deregulation".

Two additional studies are especially relevant to our analysis since they deal with the same types of financial institutions thrifts - that are the focus of our study. These studies show that the influence of shareholders (and ownership structure more generally) on risk taking behavior is especially important in the thrift industry, perhaps because of the high degree of leverage in the industry. Esty (1997a,b) presents evidence that risk taking is greater in shareholder-controlled thrifts than in mutual associations and that risk taking increases following conversion from mutual to stock ownership.

We extend this line of inquiry by returning to the thrift crisis of the late 1980s. The thrift crisis provides a fresh perspective on the relation between governance, CEO power and firm performance. Unlike the current credit crisis, where TARP assistance clouds performance measures, more than 1,000 thrifts failed during the thrift crisis with direct costs to the US government estimated at $\$ 152$ billion (Curry and Shibut, 2000). Further, the thrift crisis offers a natural experiment that mitigates the typical endogeneity concerns that accompany governance studies, because the entire industry suffered an exogenous shock exposing all thrifts to extreme financial pressure. Moreover, the industry operated in a deregulated environment pushing managers to increase the risk of the institution in order to exploit the deposit insurance subsidy.

During the thrift crisis of the late 1980s, thrifts earned negative profits and most did not meet minimum capital standards (at least not without regulatory forbearance). These circumstances are so eerily similar to recent conditions that a columnist for the Wall Street Journal stated "this wink-wink accounting, letting banks act as if they have bigger capital cushions than they do, is a remake of an old movie: the savings-and-loan horror show of the 1980s". Thus, the adjectives unitary and dual are organizational characteristics with unitary leadership referring to a single CEO/Chairman and dual leadership referring to two leaders.

From a public policy perspective, the important issue is not the effects of governance structures on the variance of stock returns or operating earnings, as has been the focus of prior studies, but on the probability of failure. Failure increases the costs of the deposit insurance system as well as the potential systemic risk for the entire financial system. Our paper focuses on this issue and asks a basic but unresolved question: Did thrifts (i.e. savings and loans) fail more or less frequently during the period of the thrift crisis if their CEO was also chair?

Consistent with Pathan (2009), we find that strong CEOs did resist shareholder pressure to seek more risk. We show that thrifts with an independent CEO and chair were significantly more likely to fail than thrifts in which one individual occupied both posts. The higher failure rate persists after controlling for other governance measures, for the composition of the loan portfolio, and for differences in the economic environment that each of the thrifts faced. Thus, unitary leadership appears to reduce the cost of the deposit insurance safety net to the residual risk bearers: taxpayers.

In light of persistent calls for mandatory separation of the CEO and chair roles, our results may surprise many policymakers. Our results suggest that requiring separation of the two roles among financial institutions could actually exacerbate the moral hazard problem posed by deposit insurance rather than prevent a recurrence of the recent financial crisis.

This paper is organized as follows. Section 2 provides the context of the thrift industry's historic evolution. Section 3 describes the sample and data. We examine univariate analysis of the sample characteristics in section 4 , followed by the results of the multivariate analysis in sections 5 and 6 concludes. 


\section{Evolutionary context of the thrift industry}

In depository institutions, in general, and thrifts, in particular, the deposit insurance agency grants the insured thrift the power to sell risk-free, government insured deposits (in effect, with $100 \%$ insurance). In return, the thrift accepts regulation by the deposit insurance agency of the decisions by management and the board of directors. The deposit insurance agency then becomes a residual claimant on the assets of the thrift and a potential participant in its governance. The insuring agent's primary goal is to limit thrift failures and thus to protect the deposit insurance fund.

Thrifts were created to provide subsidized funding to individuals to encourage home ownership. This social role is reflected by the fact that all thrifts were originally mutuals, and by the requirement of legislation such as the Community Reinvestment Act that thrifts meet their community's credit needs, especially the needs of low and moderate income individuals. Consistent with this regulated objective, thrift portfolio choices were originally subject to severe regulatory constraints. As a result, the dual objectives of board members - benefiting shareholders and controlling risks to protect the deposit insurance fund - were well aligned. However, the investment constraints of thrifts were lifted through a series of legislative actions in early 1980s. Because deposit insurance subsidized risky investment strategies during this period, these new powers for thrifts, coupled with the changed risk incentives, drove a wedge between directors' dual responsibilities.

Prior to the 1980s, savings and loan associations (or thrifts) were primarily a vehicle for accumulating the funds of relatively small, risk-averse savers to provide long-term, fixed-rate mortgages for homeowners. Regulations limited the types of assets thrifts could hold, how they could raise money to fund those assets, the interest rates they could pay, and their geographic expansion. By allowing thrifts to offer slightly higher passbook rates than banks, and limiting the alternatives available to small depositors (for instance by increasing the minimum investment in Treasury Bills from $\$ 1,000$ to $\$ 10,000$ ), regulators managed to prevent depositors from leaving thrifts for higher interest rate instruments.

As interest rates rose in the late 1970s investors began to look for instruments that paid market rates of return. Since thrift income was tied to fixed-rate mortgages (often issued years earlier at very low rates), offering higher rates on deposits would generate losses. Fine-tuning interest rate caps was not sufficient to keep deposits in low interest thrift passbook accounts. Money market mutual funds, although not federally insured, offered a relatively secure means to obtain market returns, and many investors shifted funds out of thrifts into them. As interest rates continued to rise thrifts found themselves in a no-win situation. They could offer higher interest rates to attract or keep deposits, but suffer operating losses, or they could continue to pay the low rates appropriate given their mortgage portfolio income, lose deposits and be forced to sell mortgages at a discount to satisfy capital requirements.

To address this 'interest rate squeeze' Congress allowed thrifts to offer adjustable rate mortgages and enacted the Depository Institutions Deregulation and Monetary Control Act (DIDMCA) of 1980 and the Garn-St Germain Depository Institutions Act of 1982. These acts allowed thrifts to invest in a much broader range of assets and liabilities and also reduced capital requirements. This policy response was designed to encourage thrifts to diversify part of their loan portfolio away from residential mortgages into shorter maturity loans, and thereby be less vulnerable to interest rate changes. With their increased asset powers, thrifts could issue credit cards, automobile loans, commercial loans and real estate construction and development loans. These shorter maturity loans would respond more quickly to interest rate changes and reduce the interest rate mismatch that was pushing many thrifts toward insolvency. In addition to new lending opportunities, these broader asset powers permitted thrifts to make direct equity investments in business ventures. The acts also phased out Regulation Q (that set interest rate ceilings thrifts could pay on passbook accounts), reduced capital requirements, and increased the maximum level of insured savings account coverage to $\$ 100,000$. Congress, however, did not shift to risk-based deposit insurance premiums or change its method of examining thrifts for safety and soundness.

As high interest rates continued into 1982, thrift losses mounted and the incentive to gamble on riskier assets grew. With deposit insurance protecting depositors, stock thrifts had little to lose but much to gain by pursuing high-risk strategies. Reflecting aggressive deposit and loan acquisition strategies, the assets of Federal Savings and Loan Insurance Corporation (FSLIC) insured thrifts grew at over 18\% per year in 1983 and 1984 with much of this growth being in the new categories of assets. As in any business, rapid growth, particularly in new product lines, stresses management skills and increases the likelihood of making mistakes. Thus, even thrifts that did not consciously make risky investments could have lower quality assets than anticipated. Regulatory supervision provided few warnings of impending problems. These new asset categories were also new to thrift examiners and there was little or no growth in thrift examination staff despite the growth in the complexity and size of the industry. ${ }^{6}$ Further aggravating the problems of thrifts during this period, regulators exercised official forbearance toward troubled institutions, effectively condoning creative, regulatory accounting practices designed to mask an institution's insolvency.

Federal regulation of the thrift industry developed separately from that of the commercial banking industry, reflecting the public policy goal of subsidizing the flow of credit to residential housing. Of particular importance, while the bank regulatory structure was fragmented among a number of different regulatory agencies, the thrift structure was concentrated in one agency - the Federal Home Loan Bank Board (FHLBB), an agency that was subject to considerable political pressure. Moreover, the FHLBB had traditionally followed less stringent examination, supervision, and enforcement policies than the federal banking agencies. As a result, once the underpriced, fixed-rate, deposit insurance system was coupled with expanded lending and investing powers for thrifts, the incentives created for opportunistic thrift managers to take excessive risk was not counterbalanced by the regulatory agency. This moral hazard resulted in the thrift crisis and massive losses to the US government.

As real estate and energy prices began to fall in the mid-1980s, the extent of those mistakes (or aggressive risk-taking) emerged. From 1986 through 1995 (the period we study), the number of federally insured thrifts roughly halved, declining from 3234 to 1645 (Curry and Shibut, 2000). By the time the thrift crisis ended, over 1,000 thrifts had failed. Deregulation changed what had been a simple one or two product industry into a complex and very competitive market driven industry. This new business environment was one that many thrift managers were unprepared for. Most had limited experience evaluating risky investments or competing for deposits with the new financial instruments customers demanded. Thus, the thrift crisis exemplifies a period when the leadership structure that most effectively assures firm survival is highlighted.

\footnotetext{
${ }^{6}$ A 1997 FDIC study reports that the thrift examination process and staff were not designed to deal with the new powers provided to the industry through deregulation. [History of the Eighties: Lessons for the Future, vol. 1: An Examination of the Banking Crisis of the 1980s and 1990s, p. 170]. Moreover, White (1991) shows that the number of thrift field examiners was actually reduced in the early 1980s and that the number of on-site examinations (audits) also declined (The Thrift Debacle, New York, Oxford Press)
} 


\section{Sample selection and data}

Because proxy filings are crucial to the collection of corporate governance data, a limitation of studying governance in the thrift industry is the relative scarcity of publicly traded thrifts. Consistent with their original social objective of providing residential loans, thrifts were originally mutual organizations and most thrifts remained mutual organizations during the period of our study. Moreover, most shareholder-owned thrifts were not publicly traded.

We gathered a sample of publicly traded thrifts during the thrift crisis period through a variety of approaches. We began with data from CRSP and Compustat but that yielded only 51 thrifts. Barth et al. (1991) compile a sample of 165 publicly traded thrifts from ten separate data sources, noting, "a comprehensive list of publicly-traded thrifts is not readily available". We thank Mary Barth for generously sharing this sample. ${ }^{7}$ After further screening this sample for the necessary stock market, accounting, and proxy statement data, we are left with a sample of 130 publicly traded thrifts operating in the mid-1980s.

We classify 84 of the 130 thrifts as survived and 46 as failed. Of the 84 non-failed or surviving thrifts, forty-five remained independent throughout the observation period and the other 39 nonfailed thrifts were acquired without government assistance. For these 39 thrifts, we reviewed press reports at the time of each of the acquisitions and records of government assistance in mergers and acquisitions. We found no press reports mentioning financial distress or government assistance, a characteristic generally associated with financial distress for firms involved in thrift acquisitions. Therefore, our initial analysis contrasts non-failed thrifts (including the acquired targets) with thrifts that failed in the face of the thrift crisis to determine whether the firms that imposed costs on taxpayers through their failure can be distinguished from their counterparts that did not fail. We also examine characteristic differences between thrifts that survived and remained independent and those that survived but were acquired without government assistance during the thrift crisis.

As Brickley and James (1986) explain, "insolvency for an insured financial institution occurs when the insurer will no longer provide deposit guarantees and the (institution's) charter is revoked". Lacking this date, we identify the failure date for each thrift as its last trading date in the CRSP file. Using this criterion, our failures took place in the period from 1987 through 1992. They are concentrated (62\%) between 1990 and 1992, following the passage of Federal Institutions Reform, Recovery and Enforcement Act (FIRREA) of 1989 that abolished the FHLBB and created and funded the Resolution Trust Corporation (RTC) with the mandate to close insolvent thrifts.

In contrast to the clustering of failures, acquisition and merger activity of sound thrifts appears unclustered. At least one acquisition occurs in all years except 1990, the year that failures peaked. Reflecting our interest in governance characteristics that distinguish thrifts that failed during the crisis from firms that did not fail, we truncate our data collection for all thrifts at 1992, the final year that failures occurred.

Table 1 shows the geographic distribution of the sample thrifts across states. While this provides a glimpse of thrift failure clustering in states with comparatively lax regulation during this period (California 9, Florida 3, and Texas 3), many thrifts were not publicly traded, so other states with similar regulatory environments (Lou-

\footnotetext{
${ }^{7}$ Barth et al. (1991, pp. 60-61) provide extensive details of their sample selection process. Hermalin and Wallace (2001) compile a similar-sized sample (104 firms) from SNL Securities, the Office of Thrift Supervision, and the Center for Research in Securities Prices for their study of executive compensation in the savings and loan industry over the 1988-1993 time span.
}

Table 1

Sample distribution by state and outcome. This table depicts the distribution of the sample of 130 publicly-traded thrifts across states of operation. The sample is also separated into thrifts that failed, thrifts that were acquired without government assistance, and thrifts that survived as independent entities between 1987 and 1992.

\begin{tabular}{|c|c|c|c|c|}
\hline State & Failed & $\begin{array}{l}\text { Survived } \\
\text { acquired }\end{array}$ & $\begin{array}{l}\text { Survived } \\
\text { independent }\end{array}$ & Total \\
\hline ALABAMA & 1 & 2 & 0 & 3 \\
\hline ARKANSAS & 1 & 0 & 0 & 1 \\
\hline ARIZONA & 1 & 0 & 0 & 1 \\
\hline CALIFORNIA & 9 & 1 & 10 & 20 \\
\hline COLORADO & 4 & 2 & 0 & 6 \\
\hline CONNECTICUT & 0 & 1 & 3 & 4 \\
\hline $\begin{array}{l}\text { DIST. OF } \\
\text { COLUMBIA }\end{array}$ & 0 & 0 & 2 & 2 \\
\hline FLORIDA & 3 & 6 & 5 & 14 \\
\hline GEORGIA & 1 & 1 & 2 & 4 \\
\hline HAWAII & 0 & 1 & 0 & 1 \\
\hline ILLINOIS & 1 & 1 & 0 & 2 \\
\hline INDIANA & 0 & 0 & 1 & 1 \\
\hline MASSACHUSETTS & 2 & 3 & 1 & 6 \\
\hline MARYLAND & 1 & 1 & 0 & 2 \\
\hline MICHIGAN & 0 & 1 & 2 & 3 \\
\hline MISSOURI & 0 & 1 & 1 & 2 \\
\hline MISSISSIPPI & 0 & 2 & 0 & 2 \\
\hline NORTH CAROLINA & 3 & 0 & 0 & 3 \\
\hline NORTH DAKOTA & 0 & 0 & 1 & 1 \\
\hline NEBRASKA & 1 & 1 & 2 & 4 \\
\hline NEW HAMPSHIRE & 2 & 1 & 0 & 3 \\
\hline NEW JERSEY & 1 & 0 & 1 & 2 \\
\hline NEVADA & 1 & 0 & 0 & 1 \\
\hline NEW YORK & 1 & 0 & 1 & 2 \\
\hline OHIO & 0 & 1 & 0 & 1 \\
\hline OKLAHOMA & 2 & 1 & 0 & 3 \\
\hline PENNSYLVANIA & 1 & 3 & 3 & 7 \\
\hline RHODE ISLAND & 1 & 0 & 0 & 1 \\
\hline SOUTH CAROLINA & 0 & 1 & 2 & 3 \\
\hline TENNESSEE & 1 & 0 & 0 & 1 \\
\hline TEXAS & 3 & 0 & 0 & 3 \\
\hline VIRGINIA & 5 & 1 & 3 & 9 \\
\hline VERMONT & 0 & 0 & 1 & 1 \\
\hline WASHINGTON & 0 & 7 & 2 & 9 \\
\hline WISCONSIN & 0 & 0 & 2 & 2 \\
\hline Total & 46 & 39 & 45 & 130 \\
\hline
\end{tabular}

isiana and Ohio) contribute no failures to our sample. The main pattern revealed by Table 1 is that our sample is widely scattered across 34 states and the District of Columbia. Therefore, our results do not reflect some isolated regional regulatory or economic phenomenon.

A list of the variables that we use in the study and of the sources of the information for those variables is contained in the appendix. Most of the data on the governance characteristics for our thrifts comes from proxy statements. This includes the size and composition of the board of directors as well as ownership by directors and block holders. We supplement the proxy data with balance sheet and income statement data from Compustat. Information on the failure or survival status of the thrifts comes from the FDIC web site, while we draw upon US census data for economic conditions in the market areas of the thrifts. All stock price data on our publicly traded thrifts comes from the Center for Research in Security Prices (CRSP) database.

From each proxy statement, we identify the occupation of each member of the board of directors and classify each according to the taxonomy of Brickley et al. (1994). Directors who are officers of the thrift and members of their immediate family are classified as employee directors. Directors who are closely associated with the firm but are not full-time employees are classified as affiliated directors. Affiliated directors include decision makers in other firms that do extensive business with the company. Following Brickley et al. (1994) and others, we classify consultants, lawyers and financiers 
Table 2

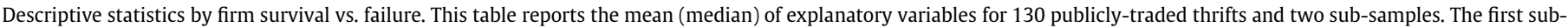

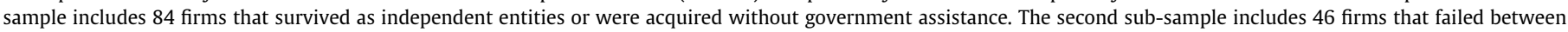

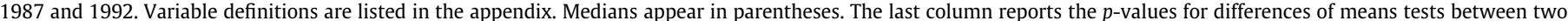
sub-samples and, in parentheses, the $p$-values of Wilcoxon rank tests for differences of medians. All statistics reflect each firm's first temporal observation.

\begin{tabular}{|c|c|c|c|c|}
\hline & $\begin{array}{l}\text { All } \\
\text { Mean } \\
\text { (median) }\end{array}$ & $\begin{array}{l}\text { (1) Survived } \\
\text { Mean } \\
\text { (median) }\end{array}$ & $\begin{array}{l}\text { (2) Failed } \\
\text { Mean } \\
\text { (median) }\end{array}$ & $\begin{array}{l}(1-2) \text { Differences of means/ } \\
\text { medians } \\
p \text {-values }\end{array}$ \\
\hline Board size & $\begin{array}{l}10.2 \\
(9.0)\end{array}$ & $\begin{array}{l}10.15 \\
(9.0)\end{array}$ & $\begin{array}{l}10.30 \\
(9.0)\end{array}$ & $\begin{array}{l}0.94 \\
(0.47)\end{array}$ \\
\hline Employee directors (\%) & $\begin{array}{l}26.6 \\
(25.0)\end{array}$ & $\begin{array}{l}25.7 \\
(22.9)\end{array}$ & $\begin{array}{l}28.3 \\
(26.8)\end{array}$ & $\begin{array}{l}0.31 \\
(0.15)\end{array}$ \\
\hline Affiliated directors (\%) & $\begin{array}{l}25.0 \\
(22.7)\end{array}$ & $\begin{array}{l}22.0 \\
(20.0)\end{array}$ & $\begin{array}{l}30.5 \\
(28.6)\end{array}$ & $\begin{array}{l}0.00 \\
(0.00)\end{array}$ \\
\hline Independent outside directors (\%) & $\begin{array}{l}48.4 \\
(50.0)\end{array}$ & $\begin{array}{l}52.4 \\
(54.4)\end{array}$ & $\begin{array}{l}41.2 \\
(42.9)\end{array}$ & $\begin{array}{l}0.00 \\
(0.00)\end{array}$ \\
\hline Percent of thrifts in which CEO is chair (\%) & $\begin{array}{l}58.5 \\
(100.0)\end{array}$ & $\begin{array}{l}66.7 \\
(100.0)\end{array}$ & $\begin{array}{l}43.5 \\
(0.0)\end{array}$ & $\begin{array}{l}0.01 \\
(0.01)\end{array}$ \\
\hline $\begin{array}{l}\text { Percent of thrifts in which CEO is chair who owns at least } 5 \% \text { of thrift's equity } \\
\text { (\%) }\end{array}$ & $\begin{array}{l}17.7 \\
(0.0)\end{array}$ & $\begin{array}{l}21.4 \\
(0.0)\end{array}$ & $\begin{array}{l}10.9 \\
(0.0)\end{array}$ & $\begin{array}{l}0.11 \\
(0.13)\end{array}$ \\
\hline Ownership of CEO (\%) & $\begin{array}{l}4.1 \\
(2.0)\end{array}$ & $\begin{array}{l}4.0 \\
(2.0)\end{array}$ & $\begin{array}{l}4.3 \\
(1.0)\end{array}$ & $\begin{array}{l}0.88 \\
(0.36)\end{array}$ \\
\hline Ownership of employee directors (\%) - net of ownership of CEO & $\begin{array}{l}2.4 \\
(1.0)\end{array}$ & $\begin{array}{l}2.2 \\
(1.0)\end{array}$ & $\begin{array}{l}2.8 \\
(1.0)\end{array}$ & $\begin{array}{l}0.45 \\
(0.23)\end{array}$ \\
\hline Ownership of affiliated directors (\%) & $\begin{array}{l}2.5 \\
(1.0)\end{array}$ & $\begin{array}{l}1.7 \\
(1.0)\end{array}$ & $\begin{array}{l}3.9 \\
(1.0)\end{array}$ & $\begin{array}{l}0.03 \\
(0.23)\end{array}$ \\
\hline Ownership of independent outside directors (\%) & $\begin{array}{l}2.6 \\
(1.0)\end{array}$ & $\begin{array}{l}3.1 \\
(2.0)\end{array}$ & $\begin{array}{l}1.7 \\
(1.0)\end{array}$ & $\begin{array}{l}0.01 \\
(0.01)\end{array}$ \\
\hline Ownership of block holdings (\%) & $\begin{array}{l}16.5 \\
(13.0)\end{array}$ & $\begin{array}{l}17.3 \\
(14.5)\end{array}$ & $\begin{array}{l}15.0 \\
(9.0)\end{array}$ & $\begin{array}{l}0.40 \\
(0.22)\end{array}$ \\
\hline Traditional loans (\%) & $\begin{array}{l}55.3 \\
(57.5)\end{array}$ & $\begin{array}{l}59.7 \\
(60.2)\end{array}$ & $\begin{array}{l}47.4 \\
(46.3)\end{array}$ & $\begin{array}{l}0.00 \\
(0.00)\end{array}$ \\
\hline Total assets (thousands) & $\begin{array}{l}3180 \\
(976)\end{array}$ & $\begin{array}{l}3030 \\
(739)\end{array}$ & $\begin{array}{l}3454 \\
(1385)\end{array}$ & $\begin{array}{l}0.67 \\
(0.05)\end{array}$ \\
\hline Number of thrifts in which CEO is chair & 76 & 56 & 20 & \\
\hline Total number of thrifts & 130 & 84 & 46 & \\
\hline
\end{tabular}

Table 3

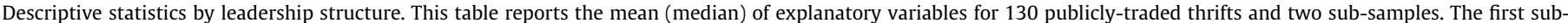

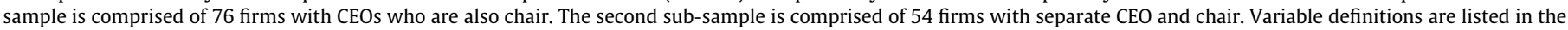

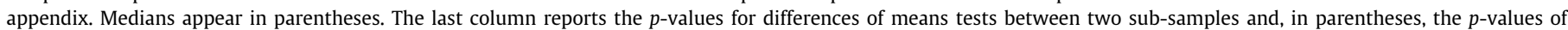
Wilcoxon rank tests for differences of medians. All statistics reflect each firm's first temporal observation.

\begin{tabular}{|c|c|c|c|c|}
\hline & $\begin{array}{l}\text { All } \\
\text { Mean } \\
\text { (median) }\end{array}$ & $\begin{array}{l}\text { (1) CEO is } \\
\text { chair } \\
\text { Mean } \\
\text { (median) }\end{array}$ & $\begin{array}{l}\text { (2) CEO is NOT } \\
\text { chair } \\
\text { Mean (median) }\end{array}$ & $\begin{array}{l}(1-2) \text { Differences of means/ } \\
\text { medians } \\
p \text {-values }\end{array}$ \\
\hline Failed (\%) & $\begin{array}{l}35.4 \\
(0.0)\end{array}$ & $\begin{array}{l}26.3 \\
(0.0)\end{array}$ & $\begin{array}{l}48.1 \\
(0.0)\end{array}$ & $\begin{array}{l}0.01 \\
(0.01)\end{array}$ \\
\hline Board size & $\begin{array}{l}10.2 \\
(9.0)\end{array}$ & $\begin{array}{l}10.25 \\
(9.0)\end{array}$ & $\begin{array}{l}10.15 \\
(9.0)\end{array}$ & $\begin{array}{l}0.96 \\
(0.54)\end{array}$ \\
\hline Employee directors (\%) & $\begin{array}{l}26.6 \\
(25.0)\end{array}$ & $\begin{array}{l}26.4 \\
(25.0)\end{array}$ & $\begin{array}{l}27.0 \\
(25.0)\end{array}$ & $\begin{array}{l}0.82 \\
(0.71)\end{array}$ \\
\hline Affiliated directors (\%) & $\begin{array}{l}25.0 \\
(22.7)\end{array}$ & $\begin{array}{l}25.1 \\
(22.2)\end{array}$ & $\begin{array}{l}24.9 \\
(24.0)\end{array}$ & $\begin{array}{l}0.93 \\
(0.96)\end{array}$ \\
\hline Independent outside directors (\%) & $\begin{array}{l}48.4 \\
(50.0)\end{array}$ & $\begin{array}{l}48.5 \\
(50.0)\end{array}$ & $\begin{array}{l}48.4 \\
(47.7)\end{array}$ & $\begin{array}{l}0.97 \\
(0.92)\end{array}$ \\
\hline $\begin{array}{l}\text { Percent of thrifts in which CEO is chair who owns at least } 5 \% \text { of thrift's } \\
\text { equity (\%) }\end{array}$ & $\begin{array}{l}17.7 \\
(0.0)\end{array}$ & $\begin{array}{l}30.3 \\
(0.0)\end{array}$ & $\begin{array}{l}0.0 \\
(0.0)\end{array}$ & $\begin{array}{l}0.00 \\
(0.00)\end{array}$ \\
\hline Ownership of CEO (\%) & $\begin{array}{l}4.1 \\
(2.0)\end{array}$ & $\begin{array}{l}5.5 \\
(2.0)\end{array}$ & $\begin{array}{l}2.1 \\
(1.0)\end{array}$ & $\begin{array}{l}0.01 \\
(0.01)\end{array}$ \\
\hline Ownership of employee directors (\%) - net of ownership of CEO & $\begin{array}{l}2.4 \\
(1.0)\end{array}$ & $\begin{array}{l}1.7 \\
(1.0)\end{array}$ & $\begin{array}{l}3.4 \\
(1.5)\end{array}$ & $\begin{array}{l}0.04 \\
(0.02)\end{array}$ \\
\hline Ownership of affiliated directors (\%) & $\begin{array}{l}2.5 \\
(1.0)\end{array}$ & $\begin{array}{l}2.3 \\
(1.0)\end{array}$ & $\begin{array}{l}2.7 \\
(1.0)\end{array}$ & $\begin{array}{l}0.60 \\
(0.57)\end{array}$ \\
\hline Ownership of independent outside directors (\%) & $\begin{array}{l}2.6 \\
(1.0)\end{array}$ & $\begin{array}{l}2.7 \\
(1.0)\end{array}$ & $\begin{array}{l}2.5 \\
(2.0)\end{array}$ & $\begin{array}{l}0.73 \\
(0.79)\end{array}$ \\
\hline Ownership of block holdings (\%) & $\begin{array}{l}16.5 \\
(13.0)\end{array}$ & $\begin{array}{l}16.8 \\
(13.7)\end{array}$ & $\begin{array}{l}16.0 \\
(11.0)\end{array}$ & $\begin{array}{l}0.76 \\
(0.38)\end{array}$ \\
\hline Traditional loans (\%) & $\begin{array}{l}55.3 \\
(57.5)\end{array}$ & $\begin{array}{l}56.1 \\
(57.2)\end{array}$ & $\begin{array}{l}54.2 \\
(57.6)\end{array}$ & $\begin{array}{l}0.55 \\
(0.64)\end{array}$ \\
\hline Total assets (thousands) & $\begin{array}{l}3180 \\
(976)\end{array}$ & $\begin{array}{l}3760 \\
(1113)\end{array}$ & $\begin{array}{l}2364 \\
(766)\end{array}$ & $\begin{array}{l}0.13 \\
(0.33)\end{array}$ \\
\hline $\begin{array}{l}\text { Number of failed thrifts } \\
\text { Total number of thrifts }\end{array}$ & $\begin{array}{l}46 \\
130\end{array}$ & $\begin{array}{l}20 \\
76\end{array}$ & $\begin{array}{l}26 \\
54\end{array}$ & \\
\hline
\end{tabular}


Table 4

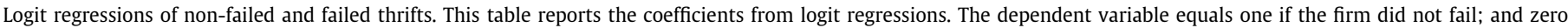

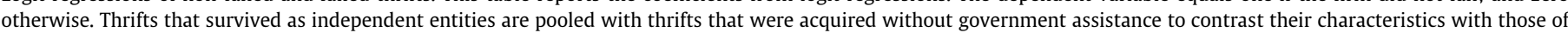

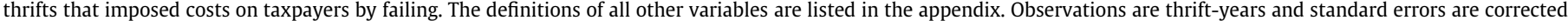
for possible lack of independence between observations for the same thrift. The $p$-values based on robust standard errors are in parentheses.

\begin{tabular}{|c|c|c|c|c|}
\hline & 1 & 2 & 3 & 4 \\
\hline Log (board size) & $\begin{array}{l}0.861 \\
(0.21)\end{array}$ & $\begin{array}{l}0.868 \\
(0.20)\end{array}$ & $\begin{array}{l}0.857 \\
(0.20)\end{array}$ & $\begin{array}{l}0.873 \\
(0.20)\end{array}$ \\
\hline Employee directors (\%) & $\begin{array}{l}-0.222 \\
(0.90)\end{array}$ & $\begin{array}{l}-0.165 \\
(0.92)\end{array}$ & & $\begin{array}{l}2.975^{*} \\
(0.09)\end{array}$ \\
\hline Affiliated directors (\%) & $\begin{array}{l}-3.129^{* *} \\
(0.03)\end{array}$ & $\begin{array}{l}-3.154^{* *} \\
(0.03)\end{array}$ & $\begin{array}{l}-2.924^{*} \\
(0.10)\end{array}$ & \\
\hline Independent outside directors (\%) & & & $\begin{array}{l}0.258 \\
(0.88)\end{array}$ & $\begin{array}{l}3.189^{* *} \\
(0.03)\end{array}$ \\
\hline Dummy (CEO is chair) & $\begin{array}{l}0.923^{*} \\
(0.05)\end{array}$ & $\begin{array}{l}0.893^{*} \\
(0.07)\end{array}$ & $\begin{array}{l}0.894^{*} \\
(0.07)\end{array}$ & $\begin{array}{l}0.891^{*} \\
(0.07)\end{array}$ \\
\hline Ownership of CEO (\%) & $\begin{array}{l}0.440 \\
(0.82)\end{array}$ & & & \\
\hline Dummy (CEO is chair and owns $\geqslant 5 \%$ equity) & & $\begin{array}{l}0.152 \\
(0.82)\end{array}$ & $\begin{array}{l}0.151 \\
(0.83)\end{array}$ & $\begin{array}{l}0.158 \\
(0.82)\end{array}$ \\
\hline Ownership of employee directors (\%) & $\begin{array}{l}-1.940 \\
(0.72)\end{array}$ & $\begin{array}{l}-2.208 \\
(0.68)\end{array}$ & $\begin{array}{l}-2.092 \\
(0.70)\end{array}$ & $\begin{array}{l}-2.129 \\
(0.69)\end{array}$ \\
\hline Ownership of affiliated directors (\%) & $\begin{array}{l}-8.215 \\
(0.12)\end{array}$ & $\begin{array}{l}-8.169 \\
(0.12)\end{array}$ & $\begin{array}{l}-8.145 \\
(0.12)\end{array}$ & $\begin{array}{l}-8.163 \\
(0.12)\end{array}$ \\
\hline Ownership of independent directors (\%) & $\begin{array}{l}7.044 \\
(0.34)\end{array}$ & $\begin{array}{l}6.851 \\
(0.35)\end{array}$ & $\begin{array}{l}6.799 \\
(0.35)\end{array}$ & $\begin{array}{l}6.826 \\
(0.35)\end{array}$ \\
\hline Ownership of block-holdings (\%) & $\begin{array}{l}2.704^{*} \\
(0.08)\end{array}$ & $\begin{array}{l}2.645^{*} \\
(0.07)\end{array}$ & $\begin{array}{l}2.645^{*} \\
(0.07)\end{array}$ & $\begin{array}{l}2.644^{*} \\
(0.08)\end{array}$ \\
\hline Traditional loans (\%) & $\begin{array}{l}6.243^{* * * *} \\
(0.00)\end{array}$ & $\begin{array}{l}6.250^{* * *} \\
(0.00)\end{array}$ & $\begin{array}{l}6.245^{* * *} \\
(0.00)\end{array}$ & $\begin{array}{l}6.241^{* * *} \\
(0.00)\end{array}$ \\
\hline Log (total assets) & $\begin{array}{l}-0.547^{* *} \\
(0.02)\end{array}$ & $\begin{array}{l}-0.547^{* *} \\
(0.02)\end{array}$ & $\begin{array}{l}-0.545^{* *} \\
(0.02)\end{array}$ & $\begin{array}{l}-0.546^{* *} \\
(0.02)\end{array}$ \\
\hline Dummy for age $\leqslant 3$ & $\begin{array}{l}-0.879^{* *} \\
(0.05)\end{array}$ & $\begin{array}{l}-0.883^{* *} \\
(0.05)\end{array}$ & $\begin{array}{l}-0.885^{* *} \\
(0.05)\end{array}$ & $\begin{array}{l}-0.887^{* *} \\
(0.05)\end{array}$ \\
\hline Population growth (basis points) & $\begin{array}{l}-0.244 \\
(0.33)\end{array}$ & $\begin{array}{l}-0.247 \\
(0.33)\end{array}$ & $\begin{array}{l}-0.247 \\
(0.33)\end{array}$ & $\begin{array}{l}-0.247 \\
(0.33)\end{array}$ \\
\hline Change in housing permits & $\begin{array}{l}0.845 \\
(0.35)\end{array}$ & $\begin{array}{l}0.839 \\
(0.35)\end{array}$ & $\begin{array}{l}0.837 \\
(0.35)\end{array}$ & $\begin{array}{l}0.828 \\
(0.36)\end{array}$ \\
\hline Dummy (liberal state) & $\begin{array}{l}0.313 \\
(0.61)\end{array}$ & $\begin{array}{l}0.316 \\
(0.61)\end{array}$ & $\begin{array}{l}0.320 \\
(0.60)\end{array}$ & $\begin{array}{l}0.318 \\
(0.61)\end{array}$ \\
\hline Dummy (federal charter) & $\begin{array}{l}-0.046 \\
(0.93)\end{array}$ & $\begin{array}{l}-0.061 \\
(0.91)\end{array}$ & $\begin{array}{l}-0.062 \\
(0.90)\end{array}$ & $\begin{array}{l}-0.062 \\
(0.90)\end{array}$ \\
\hline Number of observations & 509 & 509 & 509 & 509 \\
\hline Pseudo $R^{2}(\%)$ & 26.85 & 26.86 & 26.86 & 26.93 \\
\hline Wald $\chi^{2}$ & 41.03 & 41.03 & 41.17 & 41.3 \\
\hline Prob $>\chi^{2}$ & 0.001 & 0.001 & 0.001 & 0.001 \\
\hline
\end{tabular}

* Values significantly different from zero at $10 \%$ are marked with respectively.

** Values significantly different from zero at $5 \%$ are marked with respectively.

*** Values significantly different from zero at $1 \%$ are marked with respectively.

as affiliated directors. Given the traditional focus of thrift lending on real estate, we classified any outside directors who were real estate developers as affiliated directors. The remaining group of outside directors, categorized as independent outside directors, includes executives of other firms that do not have extensive business relations with the company, as well as public directors and private investors that are not employees or affiliated directors.

Finally, we include a number of control variables that have been shown to be important in other studies of thrifts. For example, we include size and age variables because Esty (1997b) shows that smaller and younger thrifts took more risk during the thrift crisis. Cebula (1997) finds that the failure rate among savings and loans varied geographically with the economic conditions of their market areas. Thus, we include two economic activity variables for the state where each sample firm is chartered: the growth in permits for new home construction and state population growth. We measure both variables as the percent change over the 3-year period immediately preceding the sample year for each observation. In its 1997 analysis of the causes of the thrift crisis, the Federal Deposit Insurance Corporation (FDIC) observed that individual states vied to create more liberal (relaxed) regulatory environments for individual savings and loans. Therefore, the regressions include two firm specific control variables: whether the thrift is headquar- tered in a state with liberal regulations, and whether the thrift is federally chartered or state chartered. ${ }^{8}$

\section{Sample characteristics and univariate analysis}

Table 2 reports the mean and median for our measures of governance for the sample thrifts. The first column of numbers represents the undifferentiated sample, while the columns labeled (1) and (2) show the mean and median statistics for the non-failed and failed subsamples respectively. The final column reports $p$-values for $T$-statistics for the difference in means across the non-failed and failed subsamples as well as $p$-values for a Wilcoxon Rank distributional test between the two subsamples. Table 3 provides similar information and test results for the same variables but compares thrifts in which the CEO is also chair with thrifts having different individuals as chair and CEO.

Table 2 reveals several ways that survived and failed thrifts differ. Note that $66.7 \%$ of the thrifts that survived the financial distress of the period had one person as the chair and CEO, relative to $43.5 \%$ of the failed thrifts. This difference is statistically signifi-

\footnotetext{
${ }^{8}$ States with more lax regulatory environments during this time were California Florida, Louisiana, Ohio and Texas.
} 
Table 5

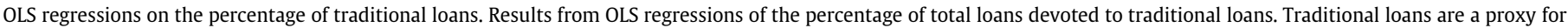

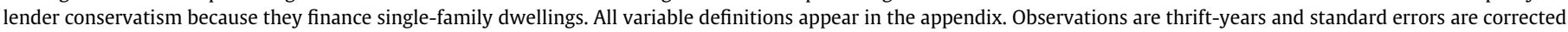
for possible lack of independence between observations for the same thrift. The $p$-values based on robust standard errors are in parentheses.

\begin{tabular}{|c|c|c|c|c|}
\hline & 1 & 2 & 3 & 4 \\
\hline Log (board size) & $\begin{array}{l}-0.046 \\
(0.26)\end{array}$ & $\begin{array}{l}-0.048 \\
(0.24)\end{array}$ & $\begin{array}{l}-0.049 \\
(0.24)\end{array}$ & $\begin{array}{l}-0.049 \\
(0.24)\end{array}$ \\
\hline Employee directors (\%) & $\begin{array}{l}-0.140 \\
(0.14)\end{array}$ & $\begin{array}{l}-0.100 \\
(0.32)\end{array}$ & & $\begin{array}{l}-0.113 \\
(0.27)\end{array}$ \\
\hline Affiliated directors (\%) & $\begin{array}{l}0.023 \\
(0.80)\end{array}$ & $\begin{array}{l}0.016 \\
(0.87)\end{array}$ & $\begin{array}{l}0.120 \\
(0.26)\end{array}$ & \\
\hline Independent outside directors (\%) & & & $\begin{array}{l}0.105 \\
(0.30)\end{array}$ & $\begin{array}{l}-0.012 \\
(0.89)\end{array}$ \\
\hline Dummy (CEO is chair) & $\begin{array}{l}0.049^{*} \\
(0.05)\end{array}$ & $\begin{array}{l}0.042 \\
(0.11)\end{array}$ & $\begin{array}{l}0.042 \\
(0.11)\end{array}$ & $\begin{array}{l}0.042 \\
(0.11)\end{array}$ \\
\hline Ownership of CEO (\%) & $\begin{array}{l}0.299^{*} \\
(0.09)\end{array}$ & & & \\
\hline Dummy (CEO is chair and owns $\geqslant 5 \%$ equity) & & $\begin{array}{l}0.057^{*} \\
(0.10)\end{array}$ & $\begin{array}{l}0.057^{*} \\
(0.10)\end{array}$ & $\begin{array}{l}0.057^{*} \\
(0.10)\end{array}$ \\
\hline Ownership of employee directors (\%) & $\begin{array}{l}0.544^{*} \\
(0.09)\end{array}$ & $\begin{array}{l}0.460 \\
(0.19)\end{array}$ & $\begin{array}{l}0.468 \\
(0.18)\end{array}$ & $\begin{array}{l}0.460 \\
(0.19)\end{array}$ \\
\hline Ownership of affiliated directors (\%) & $\begin{array}{l}0.362^{* *} \\
(0.03)\end{array}$ & $\begin{array}{l}0.367^{* *} \\
(0.03)\end{array}$ & $\begin{array}{l}0.367^{* *} \\
(0.03)\end{array}$ & $\begin{array}{l}0.371^{* *} \\
(0.03)\end{array}$ \\
\hline Ownership of independent directors (\%) & $\begin{array}{l}0.199 \\
(0.63)\end{array}$ & $\begin{array}{l}0.183 \\
(0.65)\end{array}$ & $\begin{array}{l}0.182 \\
(0.65)\end{array}$ & $\begin{array}{l}0.179 \\
(0.66)\end{array}$ \\
\hline Ownership of blockholdings (\%) & $\begin{array}{l}0.076 \\
(0.36)\end{array}$ & $\begin{array}{l}0.044 \\
(0.61)\end{array}$ & $\begin{array}{l}0.044 \\
(0.61)\end{array}$ & $\begin{array}{l}0.043 \\
(0.61)\end{array}$ \\
\hline Log (total assets) & $\begin{array}{l}0.034^{* *} \\
(0.01)\end{array}$ & $\begin{array}{l}0.035^{* * *} \\
(0.01)\end{array}$ & $\begin{array}{l}0.035^{* * *} \\
(0.01)\end{array}$ & $\begin{array}{l}0.035^{* *} \\
(0.01)\end{array}$ \\
\hline Dummy (age $\leqslant 3$ ) & $\begin{array}{l}0.015 \\
(0.53)\end{array}$ & $\begin{array}{l}0.014 \\
(0.56)\end{array}$ & $\begin{array}{l}0.014 \\
(0.56)\end{array}$ & $\begin{array}{l}0.013 \\
(0.56)\end{array}$ \\
\hline Population growth (basis points) & $\begin{array}{l}-0.032^{*} \\
(0.06)\end{array}$ & $\begin{array}{l}-0.032^{*} \\
(0.06)\end{array}$ & $\begin{array}{l}-0.032^{*} \\
(0.06)\end{array}$ & $\begin{array}{l}-0.032 \\
(0.06)\end{array}$ \\
\hline Change in housing permits & $\begin{array}{l}0.115^{* *} \\
(0.03)\end{array}$ & $\begin{array}{l}0.114^{* *} \\
(0.03)\end{array}$ & $\begin{array}{l}0.113^{* *} \\
(0.03)\end{array}$ & $\begin{array}{l}0.114^{* *} \\
(0.03)\end{array}$ \\
\hline Dummy (liberal state) & $\begin{array}{l}0.025 \\
(0.60)\end{array}$ & $\begin{array}{l}0.026 \\
(0.59)\end{array}$ & $\begin{array}{l}0.026 \\
(0.58)\end{array}$ & $\begin{array}{l}0.026 \\
(0.59)\end{array}$ \\
\hline Dummy (federal charter) & $\begin{array}{l}-0.014 \\
(0.62)\end{array}$ & $\begin{array}{l}-0.020 \\
(0.49)\end{array}$ & $\begin{array}{l}-0.020 \\
(0.49)\end{array}$ & $\begin{array}{l}-0.020 \\
(0.48)\end{array}$ \\
\hline Number of observations & 509 & 509 & 509 & 509 \\
\hline Adjusted $R$-squared (\%) & 13.90 & 12.80 & 12.80 & 12.80 \\
\hline$F$ test & 2.94 & 2.83 & 2.84 & 2.82 \\
\hline Prob $>F$ & 0.001 & 0.001 & 0.001 & 0.001 \\
\hline
\end{tabular}

* Values significantly different from zero at $10 \%$ are marked with respectively.

** Values significantly different from zero at $5 \%$ are marked with respectively.

*** Values significantly different from zero at $1 \%$ are marked with respectively.

cant at the $1 \%$ level. We also find that thrifts that survived the crisis maintained a significantly higher percentage of their assets in safer, traditional (single family dwelling) loans than did thrifts that failed. Taken together, this preliminary evidence suggests that financial institutions with strong CEOs are less likely to succumb to pressure to make more risky loans to exploit underpriced deposit insurance.

Other characteristics that differ significantly between the two groups include a lower percentage of affiliated directors and higher percentage of independent directors on the boards of thrifts that survived. The more numerous independent directors in the thrifts that survived also own significantly more shares than their counterparts on the boards of thrifts that failed.

Table 3 focuses on the differences in characteristics between thrifts with a single person as CEO and chair vs. thrifts that separated the two positions. The association between unitary leadership and failure is striking. Only $26.3 \%$ of the thrifts with unitary leadership failed relative to a failure rate of $48.1 \%$ for thrifts with dual leadership structure. Moreover, in $30.3 \%$ of the firms in which the CEO was chair, the CEO also owned more than $5 \%$ of the equity. In contrast, there are no instances where the CEO was not chair in which the CEO owned more than $5 \%$ of the equity. This suggests that, in unitary leadership situations, the CEO was powerful not only because of holding both posts but also because of a substantial equity position. Other significant differences between those thrifts in which the CEO was also chair and the other thrifts include greater overall CEO ownership (5.5\% vs. $2.1 \%$ ) and less ownership of employee directors (1.7\% vs. 3.4\%). Both characteristics tend to increase the power of the CEO. In contrast, we do not observe any statistically significant differences in the other board characteristics or in the total assets or portfolio allocation to traditional loans between those thrifts with unitary leadership and those without.

These univariate comparisons suggest that distressed financial firms were more likely to survive with a strong CEO, with a CEO who is also the firm's chair and with a CEO who has a substantial equity share in the organization. However, these implications from Tables 2 and 3 must be qualified with the recognition that other factors may be obscuring any true relationships. To properly assess our initial results, we turn to multivariate tests.

\section{Multivariate analysis}

\subsection{Logistic regressions}

The sample thrifts face three possible outcomes during the crisis: failure, surviving as independent entities, and surviving to be acquired. As our focus is on the costs imposed on taxpayers when financial institutions fail, we begin by pooling thrifts that survived 
Table 6

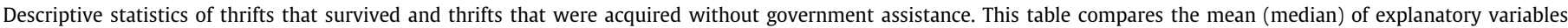

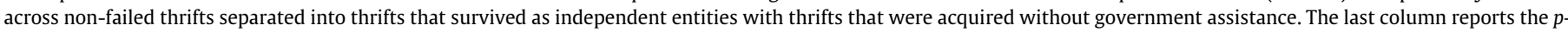

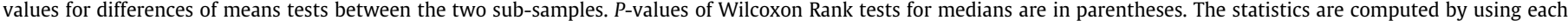
firm's first observation.

\begin{tabular}{|c|c|c|c|}
\hline & $\begin{array}{l}\text { Survived non-acquired mean } \\
\text { (median) }\end{array}$ & $\begin{array}{l}\text { Survived and acquired mean } \\
\text { (median) }\end{array}$ & $\begin{array}{l}\text { Differences of means/medians } \\
p \text {-values }\end{array}$ \\
\hline Board size & $\begin{array}{l}10.56 \\
(10.00)\end{array}$ & $\begin{array}{l}9.69 \\
(8.00)\end{array}$ & $\begin{array}{l}0.70 \\
(0.04)^{* *}\end{array}$ \\
\hline Employee directors (\%) & $\begin{array}{l}0.28 \\
(0.24)\end{array}$ & $\begin{array}{l}0.24 \\
(0.25)\end{array}$ & $\begin{array}{l}0.92 \\
(0.61)\end{array}$ \\
\hline Affiliated directors (\%) & $\begin{array}{l}0.20 \\
(0.20)\end{array}$ & $\begin{array}{l}0.25 \\
(0.22)\end{array}$ & $\begin{array}{l}0.91 \\
(0.33)\end{array}$ \\
\hline Independent outside directors (\%) & $\begin{array}{l}0.52 \\
(0.53)\end{array}$ & $\begin{array}{l}0.52 \\
(0.57)\end{array}$ & $\begin{array}{l}0.98 \\
(0.83)\end{array}$ \\
\hline Percent of thrifts in which CEO is chair (\%) & $\begin{array}{l}0.71 \\
(1.00)\end{array}$ & $\begin{array}{l}0.62 \\
(1.00)\end{array}$ & $\begin{array}{l}0.89 \\
(0.36)\end{array}$ \\
\hline $\begin{array}{l}\text { Percent of thrifts in which CEO is chair who owns at least } 5 \% \text { of } \\
\text { thrift's equity (\%) }\end{array}$ & $\begin{array}{l}0.24 \\
(0.00)\end{array}$ & $\begin{array}{l}0.18 \\
(0.00)\end{array}$ & $\begin{array}{l}0.92 \\
(0.47)\end{array}$ \\
\hline Ownership of CEO (\%) & $\begin{array}{l}0.05 \\
(0.02)\end{array}$ & $\begin{array}{l}0.03 \\
(0.02)\end{array}$ & $\begin{array}{l}0.91 \\
(0.99)\end{array}$ \\
\hline Ownership of employee directors (\%) - net of ownership of CEO & $\begin{array}{l}0.08 \\
(0.03)\end{array}$ & $\begin{array}{l}0.05 \\
(0.03)\end{array}$ & $\begin{array}{l}0.89 \\
(0.62)\end{array}$ \\
\hline Ownership of affiliated directors (\%) & $\begin{array}{l}0.02 \\
(0.00)\end{array}$ & $\begin{array}{l}0.02 \\
(0.01)\end{array}$ & $\begin{array}{l}0.99 \\
(0.18)\end{array}$ \\
\hline Ownership of independent outside directors (\%) & $\begin{array}{l}0.03 \\
(0.02)\end{array}$ & $\begin{array}{l}0.03 \\
(0.02)\end{array}$ & $\begin{array}{l}0.97 \\
(0.57)\end{array}$ \\
\hline Block holdings (\%) & $\begin{array}{l}0.16 \\
(0.14)\end{array}$ & $\begin{array}{l}0.19 \\
(0.16)\end{array}$ & $\begin{array}{l}0.95 \\
(0.56)\end{array}$ \\
\hline Traditional loans (\%) & $\begin{array}{l}0.66 \\
(10.56)\end{array}$ & $\begin{array}{l}0.64 \\
(9.69)\end{array}$ & $\begin{array}{l}0.95 \\
(0.70)\end{array}$ \\
\hline Total assets (thousands) & $\begin{array}{l}4036.0 \\
(1050.0)\end{array}$ & $\begin{array}{l}1890.4 \\
(688.1)\end{array}$ & $\begin{array}{l}0.03^{* *} \\
(0.24)\end{array}$ \\
\hline Total number of thrifts & 45 & 39 & \\
\hline
\end{tabular}

* The $p$-values of significant differences between the groups are $10 \%$ levels of significance.

*** The $p$-values of significant differences between the groups are $1 \%$ levels of significance.

** The $p$-values of significant differences between the groups are marked with $5 \%$ for levels of significance.

independently and thrifts that were acquired. We examined the records of all acquired thrifts and determined that none were distressed at the time that the acquisition occurred, thus only failed thrifts imposed costs on taxpayers.

We refer to this pooled group of thrifts as non-failed thrifts. In the logistic analysis, non-failed thrifts are coded one and failed thrifts are coded zero. Thus, significantly positive coefficients indicate that the explanatory variable increases the thrift's prospects of survival during the crisis. For this table, we use the term survival to describe the pool of non-failed thrifts.

Beginning with logistic model 1 on Table 4, we see that the likelihood of survival is inversely related to the percentage of affiliated directors on the thrift's board. The likelihood of surviving the thrift crisis increases with unitary leadership (CEO is chair), and with the percentage of block ownership, consistent with the results of Knopf and Teall (1996). Somewhat unexpectedly, none of our measures of executive share ownership affect the likelihood of survival. As expected, the likelihood of survival increases for thrifts with less aggressive lending policies (i.e., a higher percentage of traditional loans) and with large $(\geqslant 5 \%)$ block-holdings of shares. Thrifts were less likely to survive the crisis if they were large (measured by the $\log$ of total assets) or newly founded.

Model 2 replaces the CEO ownership percentage with a dummy variable coded one if a CEO is both the chair and owns $5 \%$ or more of the thrift's shares, however, this variable is not significant and has no discernible influence on the other coefficient estimates. Model 3 replaces the percentage of employee directors on the board with the percentage of independent directors on the board. Taken together, models 2 and 3 indicate that affiliated directors are the director class who truly affect the likelihood of survival. If, as in model 4 , we exclude the percentage of affiliated directors and include both the percentage of employee directors and the percentage of independent directors, both are positively significant. However, the preceding models demonstrate that these variables have an insignificant effect when the percentage of affiliated directors is included in the model. ${ }^{9}$

In summary, thrifts are less likely to fail if they have unitary leadership, if they have fewer affiliated directors, if they have more block ownership, if they are smaller, and if they make more traditional loans. This final item seems something of a tautology, so we examine the characteristics related to the use of a more conservative loan strategy.

\subsection{Traditional loans}

Table 5 reports the results of OLS regressions meant to understand the characteristics of thrifts that maintained a conservative strategy of focusing on traditional loans. Model 1 shows a significant positive relation between the percentage of traditional loans

\footnotetext{
${ }^{9}$ On the advice of our referee, we applied a recursive bivariate probit procedure to determine whether endogeneity problems persist despite the economy-wide shock of the thrift crisis. Following Greene (2008, pp. 823-826), each model in Table 4 is replaced with a 2-equation system coupling each of the four survival regressions with an equation modeling the firm's leadership dummy as a function of the firm's other governance and firm characteristics. This procedure yields a tetrachoric correlation that "measures the correlation between the disturbances in the equations, the omitted factors. That is, $\rho$, measures (roughly) the correlation between the outcomes after the influence of the included variables is accounted for. Under the null hypothesis that rho equals zero, the model consists of independent probit equations, which can be estimated separately". For each of our four models, the tetrachoric correlation was insignificant $\left[\rho_{1}=0.681 \quad(p\right.$-value $=0.254), \rho_{2}=0.545(p$ value $=0.403), \rho_{3}=0.543(p$-value $=0.395)$, and $\rho_{4}=0.544(p$-value $\left.=0.402)\right]$. Thus the natural experiment posed by the thrift crisis appears to have successfully alleviated the potential endogeneity problems normally associated with governance tests.
} 
Table 7

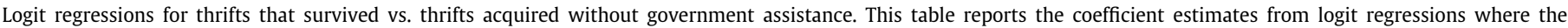

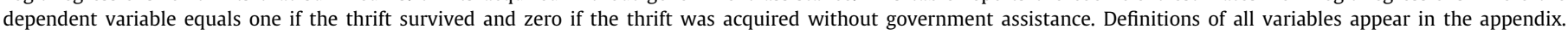

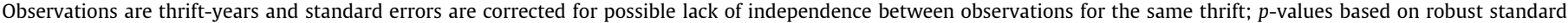
errors are in parentheses.

\begin{tabular}{|c|c|c|c|c|}
\hline & 1 & 2 & 3 & 4 \\
\hline Log (board size) & $\begin{array}{l}1.259 \\
(0.22)\end{array}$ & $\begin{array}{l}0.983 \\
(0.31)\end{array}$ & $\begin{array}{l}1.013 \\
(0.29)\end{array}$ & $\begin{array}{l}0.984 \\
(0.30)\end{array}$ \\
\hline Employee directors (\%) & $\begin{array}{l}-1.785 \\
(0.44)\end{array}$ & $\begin{array}{l}-1.248 \\
(0.57)\end{array}$ & & $\begin{array}{l}2.290 \\
(0.36)\end{array}$ \\
\hline Affiliated directors (\%) & $\begin{array}{l}-3.885^{* *} \\
(0.03)\end{array}$ & $\begin{array}{l}-3.734^{* *} \\
(0.03)\end{array}$ & $\begin{array}{l}-2.622 \\
(0.32)\end{array}$ & \\
\hline Independent outside directors (\%) & & & $\begin{array}{l}1.042 \\
(0.64)\end{array}$ & $\begin{array}{l}3.543^{* *} \\
(0.04)\end{array}$ \\
\hline Dummy (CEO is chair) & $\begin{array}{l}0.368 \\
(0.46)\end{array}$ & $\begin{array}{l}0.307 \\
(0.53)\end{array}$ & $\begin{array}{l}0.303 \\
(0.53)\end{array}$ & $\begin{array}{l}0.312 \\
(0.52)\end{array}$ \\
\hline Ownership of CEO (\%) & $\begin{array}{l}13.591^{*} \\
(0.10)\end{array}$ & & & \\
\hline Dummy (CEO is chair and owns $\geqslant 5 \%$ equity) & & $\begin{array}{l}1.279^{*} \\
(0.05)\end{array}$ & $\begin{array}{l}1.283^{*} \\
(0.05)\end{array}$ & $\begin{array}{l}1.265^{*} \\
(0.06)\end{array}$ \\
\hline Ownership of employee directors (\%) & $\begin{array}{l}9.622 \\
(0.17)\end{array}$ & $\begin{array}{l}8.292 \\
(0.16)\end{array}$ & $\begin{array}{l}7.997 \\
(0.18)\end{array}$ & $\begin{array}{l}8.526 \\
(0.15)\end{array}$ \\
\hline Ownership of affiliated directors (\%) & $\begin{array}{l}4.205 \\
(0.40)\end{array}$ & $\begin{array}{l}2.839 \\
(0.56)\end{array}$ & $\begin{array}{l}2.709 \\
(0.57)\end{array}$ & $\begin{array}{l}2.531 \\
(0.60)\end{array}$ \\
\hline Ownership of independent directors (\%) & $\begin{array}{l}-2.742 \\
(0.64)\end{array}$ & $\begin{array}{l}-2.718 \\
(0.65)\end{array}$ & $\begin{array}{l}-2.543 \\
(0.67)\end{array}$ & $\begin{array}{l}-2.457 \\
(0.68)\end{array}$ \\
\hline Ownership of block-holdings (\%) & $\begin{array}{l}2.316 \\
(0.16)\end{array}$ & $\begin{array}{l}1.600 \\
(0.34)\end{array}$ & $\begin{array}{l}1.600 \\
(0.34)\end{array}$ & $\begin{array}{l}1.601 \\
(0.34)\end{array}$ \\
\hline Log (total assets) & $\begin{array}{l}0.238 \\
(0.38)\end{array}$ & $\begin{array}{l}0.258 \\
(0.35)\end{array}$ & $\begin{array}{l}0.251 \\
(0.36)\end{array}$ & $\begin{array}{l}0.259 \\
(0.34)\end{array}$ \\
\hline Traditional loans (\%) & $\begin{array}{l}-0.069 \\
(0.97)\end{array}$ & $\begin{array}{l}0.262 \\
(0.87)\end{array}$ & $\begin{array}{l}0.287 \\
(0.86)\end{array}$ & $\begin{array}{l}0.238 \\
(0.88)\end{array}$ \\
\hline Dummy (age $\leqslant 3$ ) & $\begin{array}{l}-0.662^{*} \\
(0.07)\end{array}$ & $\begin{array}{l}-0.708^{*} \\
(0.06)\end{array}$ & $\begin{array}{l}-0.706^{*} \\
(0.06)\end{array}$ & $\begin{array}{l}-0.700^{*} \\
(0.06)\end{array}$ \\
\hline Population growth (basis points) & $\begin{array}{l}0.158 \\
(0.59)\end{array}$ & $\begin{array}{l}0.144 \\
(0.63)\end{array}$ & $\begin{array}{l}0.140 \\
(0.64)\end{array}$ & $\begin{array}{l}0.139 \\
(0.64)\end{array}$ \\
\hline Change in housing permits & $\begin{array}{l}0.160 \\
(0.82)\end{array}$ & $\begin{array}{l}0.054 \\
(0.94)\end{array}$ & $\begin{array}{l}0.044 \\
(0.95)\end{array}$ & $\begin{array}{l}0.034 \\
(0.96)\end{array}$ \\
\hline Dummy (liberal state) & $\begin{array}{l}0.070 \\
(0.93)\end{array}$ & $\begin{array}{l}0.102 \\
(0.91)\end{array}$ & $\begin{array}{l}0.099 \\
(0.91)\end{array}$ & $\begin{array}{l}0.109 \\
(0.90)\end{array}$ \\
\hline Dummy (federal charter) & $\begin{array}{l}0.246 \\
(0.67)\end{array}$ & $\begin{array}{l}0.233 \\
(0.69)\end{array}$ & $\begin{array}{l}0.243 \\
(0.67)\end{array}$ & $\begin{array}{l}0.247 \\
(0.67)\end{array}$ \\
\hline Number of observations & 386 & 386 & 386 & 386 \\
\hline Pseudo R-squared (\%) & 16.74 & 14.03 & 13.96 & 13.77 \\
\hline Wald $\chi^{2}$ & 23.4 & 23.73 & 23.6 & 23.45 \\
\hline Prob $>\chi^{2}$ & 0.103 & 0.096 & 0.099 & 0.102 \\
\hline
\end{tabular}

*** Values significantly different from zero at $1 \%$.

* Values significantly different from zero at $10 \%$ are marked with respectively.

** Values significantly different from zero at $5 \%$ are marked with respectively.

and unitary leadership. The percentage of traditional loans is also positively related to the percentage of shares owned by the CEO, the employee directors, and the affiliated directors. Finally, the traditional loan use is also positively related to the thrift's size.

Recalling the results of the preceding table, the only characteristic that is significantly and positively related to both the percentage of traditional loans and thrift survival is unitary leadership. Although board structure, especially the percentage of affiliated directors on the board, significantly affected the likelihood of failure, no measures of board structure influence the use of traditional loans. Similarly, block ownership is unrelated to the use of traditional loans, yet it significantly increases the likelihood of survival. On the other hand, the ownership of the CEO and of both employee and affiliated directors is positively related to the thrift's use of traditional loans even though they are unrelated to the likelihood of survival. This regression tells us that larger thrifts used more traditional loans, yet they were also less likely to survive according to our previous regression. Naturally, thrifts in regions where housing permit issuance was increasing issued a greater percentage of traditional loans.

As in the previous table, model 2 replaces the CEO ownership percentage with a dummy variable coded one if a CEO is both the chair and owns $5 \%$ or more of the thrift's shares. In contrast to the results in Table 4, where the variable for the CEO is chair and owns $>5 \%$ never approached significance, in the context of traditional loans it is significantly positive $(p$-value $=0.10)$ and it appropriates the explanatory power of the CEO is chair dummy (whose $p$-value increases from 0.05 to 0.11 ). This suggests that powerful CEOs (those with both leadership posts and who own at least $5 \%$ of the thrift's shares) are more disposed to employ a conservative lending strategy than CEO-chairs who own less than $5 \%$ of the thrift's shares. Yet, it is the CEO-chairs regardless of their shareholdings who increase the thrift's likelihood of survival. Returning to Table 4, we might say that, after controlling for the riskiness inherent in the thrift's loan portfolio (and all the other explanatory variables in the logit regressions), unitary leadership significantly improves a thrift's likelihood of survival.

Models 3 and 4 incorporate the changes to board structure that were made in Table 4, but as noted earlier, board structure has no influence on the reliance on traditional loans, so the conclusions from models 3 and 4 coincide with our conclusions from model 2 .

\subsection{Analysis of the acquired vs. the surviving non-acquired thrifts}

The preceding section contrasts 46 thrifts that failed with a comingled pool of 84 non-failed thrifts, of which 45 survived as 
independent entities while 39 were acquired by other institutions without government assistance. We justified this simplification by our interest in failed thrifts that imposed costs on taxpayers and by asserting that none of these 39 acquired thrifts were distressed at the time of acquisition. In this section, we search for significant differences between non-failed acquired thrifts and other surviving thrifts.

Table 6 presents univariate statistics and test results for the difference between the non-failed acquired thrifts and the other nonfailed thrifts. Thrifts that survived and remained independent are roughly twice the size of thrifts that were acquired. The difference is significant using a means test but insignificant using a median test. Thrifts that survived and remained independent have more board members than thrifts that were acquired with a mean (median) of 10.6 (10.0) vs. 9.7 (8.0) board members. This difference is significant for the median test but not for the mean test.

These subsamples appear similar in almost all dimensions, but univariate comparisons may fail to detect important differences, so in Table 7 we use logit regressions to compare thrifts that were acquired to thrifts that survived independently. Acquired thrifts are coded zero, and independent survivor thrifts are coded one. ${ }^{10}$

As in the logit models that included failed thrifts, some of the board composition variables are significant. The likelihood that a non-failed firm remains independent is higher with more independent outside directors and fewer affiliated or grey directors, in contrast to the findings of Cook et al. (2004) for a subsequent interval. The only other variables with statistically significant coefficients are the CEO equity ownership variables. That surviving thrifts that are eventually acquired have lower CEO ownership than those that remain independent is consistent with the results of Shivdasani (1993). Higher CEO ownership could indicate a higher cost of acquisition for a bidder, so these surviving thrifts were not targeted.

There is no discernible difference in the leadership structure of the independent surviving thrifts and the non-failed acquired thrifts. Thus, unitary leadership is associated with survival, either as an independent firm or as a financially viable thrift that is acquired. These results suggest that government policymakers who, after the 2008-2009 financial crisis, are currently calling for the separation of the CEO and board chair positions in financial institutions may not be reducing the risk of these institutions failing during a future financial crisis.

\section{Conclusion}

This paper provides the first explicit tests of whether unitary leadership protects the interests of taxpayers who become the residual claimants when financial institutions exploit underpriced deposit insurance through more risky investment policies. We make no attempt to consider shareholders' best interests. Failure means that shareholders lose, but limited liability assures that they lose no more than their equity stake in the firm and such losses may be nothing more than the bad ex post outcome of a rational ex ante investment to a diversified investor.

We employ a natural experiment that preceded the ubiquitous governance alarms of recent decades. We find that thrifts whose CEOs chaired their boards were significantly less likely to fail during the thrift crisis of the late 1980s than their counterparts in which CEOs were not board chairs. These results are robust to tests for endogeneity. Thus, CEOs of thrifts who chair their boards appear to protect taxpayer interests by resisting shareholder pressure to adopt riskier investment strategies to exploit underpriced deposit insurance. Mandating the separation of these posts may run counter to taxpayer interests.

\footnotetext{
$\overline{10}$ A multinomial logistic analysis comparing failed, non-failed acquired and nonfailed survived thrifts produced qualitatively similar results.
}

Despite a lack of clear evidence against unitary leadership, calls for the mandatory separation persistently surface whenever corporate governance issues are debated. As regulators across the globe once again consider how to revamp regulations to forestall future crises, the possibility exists that conventional beliefs about shareholder interests may impose unrecognized costs on society.

We view our evidence as yet another example of how dangerous it is to rely on our collective intuition when regulating something as complex as a firm's governance. These unforeseen hazards are likely greater in the financial sector with its many different and ever changing regulations. Policymakers clamoring for the separation of the CEO and chair positions in financial institutions may inadvertently increase the risk of these institutions failing during a future financial crisis. Perhaps Congress should heed Adams' (2011) cautionary advice that "(u)ntil the governance of financial firms is better understood, it may be better not to impose restrictions on the governance of financial firms".

\section{Acknowledgements}

We thank Bert Cannella, Robert Kieschnick, Jerry Martin, Kyle Tippens and seminar participants at the 2010 Australasian Banking and Finance Conference and the University of Arizona for helpful comments. Lee gratefully acknowledges financial support from Texas A\&M University's Private Enterprise Research Center.

Appendix A. List of variables

\begin{tabular}{|c|c|c|}
\hline \multicolumn{2}{|c|}{ Variables in regressions } & \multirow{2}{*}{$\begin{array}{l}\text { Data source } \\
\text { FDIC }\end{array}$} \\
\hline Failed/survived & $\begin{array}{l}=0 \text { for failed thrifts; } \\
=1 \text { for survived } \\
\text { thrifts }\end{array}$ & \\
\hline Traditional loans & $\begin{array}{l}\text { Ratio of traditional } \\
\text { loans to total loans } \\
\text { Traditional loans } \\
\text { are for single- } \\
\text { family dwellings }\end{array}$ & $\begin{array}{l}\text { Q-file proxy } \\
\text { statements }\end{array}$ \\
\hline Board size & $\begin{array}{l}\text { Natural logarithm } \\
\text { of number of board } \\
\text { members }\end{array}$ & $\begin{array}{l}\text { Q-file proxy } \\
\text { statements }\end{array}$ \\
\hline $\begin{array}{l}\text { Employee } \\
\text { directors }\end{array}$ & $\begin{array}{l}\text { Percentage of } \\
\text { inside board } \\
\text { members }\end{array}$ & $\begin{array}{l}\text { Q-file proxy } \\
\text { statements }\end{array}$ \\
\hline $\begin{array}{l}\text { Affiliated } \\
\text { directors }\end{array}$ & $\begin{array}{l}\text { Percentage of } \\
\text { affiliated board } \\
\text { members }\end{array}$ & $\begin{array}{l}\text { Q-file proxy } \\
\text { statements }\end{array}$ \\
\hline $\begin{array}{l}\text { Independent } \\
\text { outside } \\
\text { directors }\end{array}$ & $\begin{array}{l}\text { Percentage of } \\
\text { independent board } \\
\text { members }\end{array}$ & $\begin{array}{l}\text { Q-file proxy } \\
\text { statements }\end{array}$ \\
\hline CEO is chair & $\begin{array}{l}=1 \text { if } \text { CEO is chair; } \\
=0 \text { otherwise }\end{array}$ & $\begin{array}{l}Q \text {-file proxy } \\
\text { statements }\end{array}$ \\
\hline $\begin{array}{l}\text { CEO is chair and } \\
\text { owns } \geqslant 5 \% \text { of } \\
\text { equity }\end{array}$ & $\begin{array}{l}=1 \text { if CEO is chair } \\
\text { and owns } \geqslant 5 \% \text { of } \\
\text { equity; }=0 \\
\text { otherwise }\end{array}$ & $\begin{array}{l}\text { Q-file proxy } \\
\text { statements }\end{array}$ \\
\hline Ownership of CEO & $\begin{array}{l}\text { Percentage of total } \\
\text { equity held by CEO }\end{array}$ & $\begin{array}{l}\text { Q-file proxy } \\
\text { statements }\end{array}$ \\
\hline $\begin{array}{l}\text { Ownership of } \\
\text { employee } \\
\text { directors - net }\end{array}$ & $\begin{array}{l}\text { Percentage of total } \\
\text { equity owned by } \\
\text { inside directors }\end{array}$ & $\begin{array}{l}\text { Q-file proxy } \\
\text { statements }\end{array}$ \\
\hline
\end{tabular}


List of variables (continued)

\begin{tabular}{|c|c|c|}
\hline \multicolumn{2}{|c|}{ Variables in regressions } & \multirow[t]{2}{*}{ Data source } \\
\hline $\begin{array}{l}\text { of ownership of } \\
\text { CEO }\end{array}$ & $\begin{array}{l}\text { (net of ownership } \\
\text { of CEO) }\end{array}$ & \\
\hline $\begin{array}{l}\text { Ownership of } \\
\text { affiliated } \\
\text { directors }\end{array}$ & $\begin{array}{l}\text { Percentage of total } \\
\text { equity owned by } \\
\text { affiliated directors }\end{array}$ & $\begin{array}{l}\text { Q-file proxy } \\
\text { statements }\end{array}$ \\
\hline $\begin{array}{l}\text { Ownership of } \\
\text { independent } \\
\text { outside } \\
\text { directors }\end{array}$ & $\begin{array}{l}\text { Percentage of total } \\
\text { equity held by } \\
\text { independent } \\
\text { directors }\end{array}$ & $\begin{array}{l}\text { Q-file proxy } \\
\text { statements }\end{array}$ \\
\hline Block-holdings & $\begin{array}{l}\text { The percentage of } \\
\text { total equity held } \\
\text { by block-holders. A } \\
\text { block is defined as } \\
\text { more than } 5 \% \text { of } \\
\text { thrift's shares }\end{array}$ & $\begin{array}{l}\text { Q-file proxy } \\
\text { statements }\end{array}$ \\
\hline Total assets & $\begin{array}{l}\text { Natural logarithm } \\
\text { of total assets }\end{array}$ & CRSP \\
\hline \multicolumn{3}{|l|}{ Control variables } \\
\hline Age & $\begin{array}{l}\text { Dummy }=1 \text { if CRSP } \\
\text { age } \leqslant 3 ;=0 \\
\text { otherwise }\end{array}$ & CRSP \\
\hline $\begin{array}{l}\text { Population } \\
\text { growth }\end{array}$ & $\begin{array}{l}\text { 3-year growth rate } \\
\text { in population of } \\
\text { chartered state (in } \\
\text { basis points) }\end{array}$ & US Census Bureau \\
\hline $\begin{array}{l}\text { Change in housing } \\
\text { permits }\end{array}$ & $\begin{array}{l}\text { Annual growth in } \\
\text { housing permits } \\
\text { for charter state }\end{array}$ & US Census Bureau \\
\hline $\begin{array}{l}\text { Dummy for liberal } \\
\text { state }\end{array}$ & $\begin{array}{l}=1 \text { if charter state } \\
\text { is CA, FL, LA, OH, or } \\
\text { TX; =0 otherwise }\end{array}$ & $\begin{array}{l}\text { FDIC - The S\&L } \\
\text { crisis and its } \\
\text { relationship to } \\
\text { banking, July } 28 \text {, } \\
1999\end{array}$ \\
\hline $\begin{array}{l}\text { Dummy for } \\
\text { federal charter }\end{array}$ & $\begin{array}{l}=1 \text { if federal } \\
\text { charter; }=0 \text { if state } \\
\text { charter }\end{array}$ & $\begin{array}{l}\text { Q-file proxy } \\
\text { statements }\end{array}$ \\
\hline
\end{tabular}

\section{References}

Adams, R., 2011. Governance and the financial crisis. Available from SSRN: <http:// ssrn.com/abstract $=1945567>$.

Adams, R., Almeida, H., Ferreira, D., 2005. Powerful CEOs and their impact on corporate performance. Review of Financial Studies 18, 1403-1432.

Akerlof, G., Romer, P., 1993. Looting: the economic underworld of bankruptcy for profit. Brookings Papers on Economic Activity 1993-2, 1-73.

Anderson, R., Fraser, D., 2000. Corporate control, bank risk taking, and the health of the banking industry. Journal of Banking and Finance 24, 1383-1398.

Baird, D., Rasmussen, R., 2007. The prime directive. University of Cincinnati Law Review 75, 921-941.

Barth, M., Beaver, W., Stinson, C., 1991. Supplemental data and the structure of thrift share prices. Accounting Review 66, 56-66.

Beltratti, A., Stulz, R., 2011. The credit crisis around the globe: why did some banks perform better? Charles A. Dice Center Working Paper No. 2010-5; Fishe
College of Business Working Paper No. 2010-03-005. SSRN: <http:// www.ssrn.com/abstract $=1572407>$.

Bhagat, S., Bolton, B., 2008. Corporate governance and firm performance. Journal of Corporate Finance 14, 257-273.

Blair, M., Stout, L., 2001. Director accountability and the mediating role of the corporate board. Washington University Law Quarterly 79, 403-449.

Brickley, J., Coles, J., Jarrell, G., 1997. Leadership structure: separating the CEO and chairman of the board. Journal of Corporate Finance 3, 189-220.

Brickley, J., Coles, J., Terry, R., 1994. Outside directors and the adoption of poison pills. Journal of Financial Economics 35, 371-390.

Brickley, J., James, C., 1986. Access to deposit insurance, insolvency rules and the stock returns of financial institutions. Journal of Financial Economics 16, 345371.

Cebula, R., 1997. An empirical analysis of determinants of geographic differentials in the savings and loan failure rate, 1989-1991, using the heteroskedastic-tobit model. Journal of Regional Analysis and Policy 27, 55-62.

Chava, S., Roberts, M., 2008. How does financing impact investment? The role of debt covenants. Journal of Finance 63, 2085-2121.

Cook, D., Hogan, A., Kieschnick, R., 2004. A study of the corporate governance of thrifts. Journal of Banking and Finance 28, 1247-1271.

Curry, T., Shibut, L., 2000. The cost of the savings and loan crisis: truth and consequences. FDIC Banking Review 13, 26-35.

Dey, A., Engel, E., Liu, X., 2009. CEO and board chair roles: to split or not to split. Chicago Booth Research Paper No. 09-23. SSRN: <http://www.ssrn.com/ abstract $=1412827>$.

Diamond, D., Dybvig, P., 1983. Bank runs, deposit insurance, and liquidity. Journal of Political Economy 91, 401-419.

Diamond, D., Dybvig, P., 1986. Banking theory, deposit insurance, and bank regulation. Journal of Business 59, 55-68.

Erkens, D., Hung, M., Matos, P., 2010. Corporate governance in the 2007-2008 financial crisis: evidence from financial institutions worldwide. ECGI - Finance Working Paper No. 249/2009. SSRN: <http://www.ssrn.com/abstract= 1397685>

Esty, B., 1997a. A case study of organizational form and risk shifting in the savings and loan industry. Journal of Financial Economics 44, 57-76.

Esty, B., 1997b. Organizational form and risk taking in the savings and loan industry. Journal of Financial Economics 44, 25-55.

Fahlenbrach, R., Stulz, R., 2011. Bank CEO incentives and the credit crisis. Journal of Financial Economics 99, 11-26.

Favaro, K., Karlsson, P.-O., Neilson, G., 2010. CEO succession 2000-2009: a decade of convergence and compression. Strategy+Business, Booz and Company.

Federal Deposit Insurance Corporation, 1997. History of the eighties: lessons for the future. An Examination of the Banking Crises of the 1980s and Early 1990s, vol. 1. FDIC, Washington, DC

Greene, W., 2008. Econometric Analysis, sixth ed. Prentice-Hall, New Jersey.

Grinstein, Y., Valles, Y., 2008. Separating the CEO from the chairman position: determinants and changes after the new corporate governance regulations. SSRN: <http://www.ssrn.com/abstract=1108368>.

Gropp, R., Köhler, M., 2010. Bank owners or bank managers: who is keen on risk? Evidence from the financial crisis. European Business School Research Paper No. 10-02. SSRN: <http://www.ssrn.com/abstract=1555663>.

Hermalin, B., Wallace, N., 2001. Firm performance and executive compensation in the savings and loan industry. Journal of Financial Economics 61, 139-170.

Knopf, J., Teall, J., 1996. Risk-taking behavior in the US thrift industry: ownership structure and regulatory changes. Journal of Banking \& Finance 20, 1329-1350.

Laeven, L., Levine, R., 2009. Bank governance, regulation and risk taking. Journal of Financial Economics 93, 259-275.

Nini, G., Smith, D., Sufi, A., 2009. Creditor control rights and firm investment policy. Journal of Financial Economics 92, 400-420.

Pathan, S., 2009. Strong boards, CEO power and bank risk-taking. Journal of Banking and Finance 33, 1340-1350.

Saunders, A., Strock, E., Travlos, N., 1990. Ownership structure, deregulation, and bank risk taking. Journal of Finance 45, 643-654.

Shivdasani, A., 1993. Board composition, ownership structure, and hostile takeovers. Journal of Accounting and Economics 16, 167-198.

Simpson, W., Gleason, A., 1999. Board structure, ownership, and financial distress in banking firms. International Review of Economics and Finance 8, 281-292.

Wessel, D., 2010. Small banks and big risks. Wall Street Journal, June 24, p. 2.

White, L., 1991. The S\&L Debacle: Public Policy Lessons for Bank and Thrift Regulation. Oxford University Press, New York. 